\title{
Social Marketing: Is It an Approach to Promote Screening Tests for Women's Cancers?
}

\author{
Mohsen Shams ${ }^{1 *}$ and Sedigheh Shariatinia ${ }^{2}$ \\ ${ }^{1}$ Health Education \& Promotion Department, Yasuj University of Medical Sciences, Iran \\ ${ }^{2}$ Isfahan University of Medical Sciences, Iran
}

Submission: September 25, 2018; Published: October 04, 2018

*Corresponding author: Mohsen Shams, Health Education \& Promotion Department,Yasuj University of Medical Sciences, Yasuj, Iran, Tel: +98 9124244471; Email: moshaisf@yahoo.com

\begin{abstract}
Cancer is a leading cause of premature death and disability, especially in women. So, the screening and early detection services are considered as important programs in public health. Educational interventions are not enough to persuade women to do screening tests and we have to consider their perceived barriers and concerns. Social marketing, as an approaches applied to achieve behavior change, uses commercial marketing principles and techniques to influence the voluntary behavior of target audiences in order to improve their personal welfare and that of their society. It provides an approach for determining the barriers and benefits that are relevant to underserved women and for designing multi-strategy interventions that reflect their service needs and preferences. So, acceptance of the idea and behavior will be cost-beneficent. This paper aimed at introducing social marketing as a less well-known approach to behavior change in the field of gynecology and its application for women cancer screening services.
\end{abstract}

Keywords: Social marketing; Cancers; Screening; Women; Health services

\section{Introduction}

\section{Cancers in women}

Cancer is a leading cause of premature death and disability, especially in women. The most common cancer in women is breast cancer, and the fourth rank belongs to cervical cancer [1]. Every year, more than two million women are diagnosed with breast or cervical cancer worldwide [2]. So, screening as the use of simple tests in a healthy population to identify patients without symptoms, and early detection as recognizing possible warning signs of cancer and taking prompt action leads to early diagnosis of cancer, have important roles in cancer prevention and control programs [3]. Cytology-based screening, known as the Pap smear, and HPV testing are two types of screening tests for cervical cancers [4]. The regular breast cancer screening such as mammography, and early detection methods such as ultrasound and breast MRI, must be considered [5]. Although, cancer screening and early detection services is generally available at the public primary health care level, the number of women who use them is not acceptable. So, persuading the women to receive these services, as a healthy behavior, is an important program in public health.

\section{Approach to behavior change in public health}

In public health, education, marketing and law enforcement, are three main approaches applied to achieve behavior change.
For people who consider the behavior change but do not have the required knowledge or skills, education is effective, and enforcement and regulation is appropriate for the entrenched people who have no desire to change and resist deliberately. The third approach is marketing, which is a good solution for those who are aware of the need to change but have not considered changing. It is used to promote an idea, behavior or service, through identifying the viewpoints of target group and design the consumer- oriented programs. So, acceptance of the idea and behavior must be cost-beneficent [6].

Social Marketing borrowed the commercial marketing and social (or behavior) change theories to set a marketing application for intervention in the social arena. In 1971, social marketing was born, when Kotler and Zaltman published their leading paper in Journal of Marketing and realized that the same marketing principles that were being used to sell products to customers could be used to "sell" ideas, attitudes and behaviors [7]. Social marketing defined as "The application of commercial marketing technologies to the analysis, planning, execution and evaluation of programs designed to influence the voluntary behavior of target audiences in order to improve their personal welfare and that of their society" [8]. So, social marketers try to influence the customers and sell their products and services. 
Social Marketing is not just advertising or communication, media campaign, reaching everyone and a fast process, since entire processes depends on the individual's active role [9]. It provides an approach for determining the barriers and benefits that are relevant to underserved women and for designing multi-strategy interventions that reflect their service needs and preferences [10].

Health is a true market in which people pay direct and indirect costs to receive the tangible health products (e.g. iron or multivitamin supplements for infants, condom for sex workers, and contraceptives for family planning), health services (e.g. chest X-ray for patients suspect to tuberculosis), and health behaviors (e.g. physical activity, smoking cessation, and reducing salt intake). On the other words, healthcare providers have something to offer their consumers, and expect the audiences to take them. The question that social marketers tries to answer is: "What can we do to persuade people to use our offered products, services, and behaviors?"

\section{Social Marketing as an Effective Approach to Promote Screening Test for Women Cancers}

Social marketing is used to persuade the women to refer and receive cancer screening tests. So, knowing about the social marketing benchmark criteria [11], can help the physicians to promote Pap smear and mammography. According to these criteria:

a) The actual behavior must be selected and focused. Referring and using the cancer screening services, are two target behaviors, and all activities must be focus on these actual behaviors.

b) The fundamental basis of social marketing programs is knowing about the audience. Formative research, as a basic step in social marketing programs, allows the social marketer to identify (a) distinct audience subgroups or segments to be targeted; (b) appropriate behavioral objectives for each target segment; and (c) the audiences' views of the product's benefits and price and other factors that influence their adoption of the proposed behavior. Results are used to develop a comprehensive marketing plan to encourage the audience segments to adopt the healthy behaviors or to use recommended health services. So, we need to know what the consumers think about the screening services as target behaviors.

c) Dividing a general target audience into smaller and homogenous segments based on the shared characteristics, called audience segmentation, results in making the intervention more effective.

d) Considering the benefits and costs of the target behavior to maximize the benefits and minimize the costs, creates an attractive exchange. Exploring the audiences' views and opinions and considering them in designing the intervention must be exchange-based. e) The audience's time, attention, and inclination to behave form the competition components. So, we need to make the screening services more cost-beneficent.

f) Marketing mix, also known as the 4Ps: product, price, place, and promotion. These four key elements of social marketing are central to the planning and implementation of an integrated marketing strategy [12].Each of these four components should be present in a marketing plan. To have an effective social marketing program, we must have a product developed based on the consumers' wants, needs, and preferences; priced realistically; distributed through convenient channels, and actively promoted to customers.

If a social marketing program is well-design and implemented, we will expect to help women to perceive the screening services as a cost-beneficent behavior. So, general practitioners, midwives, and gynecologists must not consider education as the only approach applied to increase coverage of screening tests. By removing the barriers or making the benefits highlighted, they help and encourage the targeted women to refer and receive the cancer screening services. In this process, persuasive messages and materials, communication channels, promotional products, and influencing persons are key elements in successful interventions.

\section{Conclusion}

Health is an important social market in which the principles and key elements of commercial marketing are applied. People enter this market and do the exchange. They pay tangible and intangible costs to buy health products, services, and behaviors. Screening and early detection services for women cancers, can be promoted through education, social marketing, and law enforcement. Using the principles and key elements of commercial marketing to encourage women to refer and use these services, is an effective approach to promote them. Health professionals must know how a social marketing is designed and implemented. Attention to social marketing usages for health problems is expanding. However, the effectiveness of the social marketing interventions is in controversial yet.

\section{References}

1. Gelband H, Jha P, Sankaranarayanan R, Gauvreau, Horton S, et al. (2015) Cancer. In: Jamison DT, Gelband H, Horton S, Jha P, Laximinarayan R, Nugent R, (eds.), Disease control priorities in developing countries, In: ( $3^{\text {rd }}$ edn), World Bank, Washington, DC, USA.

2. Ginsburg O, Bray F, Coleman MP, Vanderpuye V, Eniu A, et al. (2017) The global burden of women's cancers: a grand challenge in global health. The Lancet 389(10071): 847-860.

3. http://www.who.int/cancer/detection/en/

4. https://www.cancer.gov/types/cervical/pap-hpv-testing-fact-sheet

5. https://www.cancer.org/cancer/breast-cancer/screening-tests-andearly-detection.html

6. Maibach EW, Rothschild ML, Novelli WD (2002) Social marketing. In: Glanz K, Rimer BK, Lewis FM (eds.), Health Behavior and Health Education, In: ( $3^{\text {rd }}$ edn), Jossey-Boss, San Francisco, USA. 
7. Kotler P, Zaltman G (1971) Social marketing: an approach to planned social change. J Mark 35(3): 3-12.

8. Andreasen AR (1994) Social Marketing: Its Definition and Domain. Journal of Public Policy \& Marketing 13(1): 108-114.

9. Silva DEC, Mazzon JA (2015) Social marketing for women's health campaigns. Journal of Public Administration and Policy Research, 7(5) 89-97.
10. Bryant CA, Forthofer MS, Cormack-Brown KM, Moya Lynn Alfonso CHES, Gwen Quinn, et al. (2000) A Social Marketing Approach to Increasing Breast Cancer Screening Rates. Journal of Health Education 31(6): 320-330

11. http://www.socialmarketing-toolbox.com/content/nsmc-benchmarkcriteria-0

12. Kotler P, Roberto N, Lee N (2002) Social Marketing: Improving the Quality of Life. In: ( $2^{\text {nd }}$ edn). Sage Thousand Oaks, CA: USA.

Your next submission with Juniper Publishers will reach you the below assets

- Quality Editorial service

- Swift Peer Review

- Reprints availability

- E-prints Service

- Manuscript Podcast for convenient understanding

- Global attainment for your research

- Manuscript accessibility in different formats ( Pdf, E-pub, Full Text, Audio)

- Unceasing customer service

Track the below URL for one-step submission https://juniperpublishers.com/online-submission.php 